\title{
Irreproducible pursues the improbable
}

[воsтоN] This year's Ig Nobel Prize ceremony - to be held next week at Harvard University under the appropriate title of 'The Big Bang' - seems likely to generate more pyrotechnics than usual, with rights to the 'Ig' trademark itself being hotly contested.

Marc Abrahams, editor of the Annals of Improbable Research (AIR), has organized the event for the past seven years. But George Scherr, a microbiologist and publisher of a rival science humour magazine, the Journal of Irreproducible Results (JIR), has sought to gain control of the term 'Ig Nobel Prize' in an application to the US Patent and Trademark Office.

Scherr is also suing Abrahams, a former editor of $J I R$, for $\$ 4.2$ million, accusing him of unfair business practices, trademark infringement, conspiracy to defraud, racketeering and other offences. The world of irreproducible results has declared war on improbable research, leaving the future of dubious science hanging in the balance.

In August, the trademark office rejected Scherr's ownership claim for the term 'Ig Nobel Prize', but Scherr has six months to appeal against that decision. He declines to discuss the trademark issue or his grievances with Abrahams other than to say: "Nature is not the proper venue for this discussion. Legal disputes should be resolved in a court of law."

Abrahams is more forthcoming, maintaining that Scherr has no legitimate

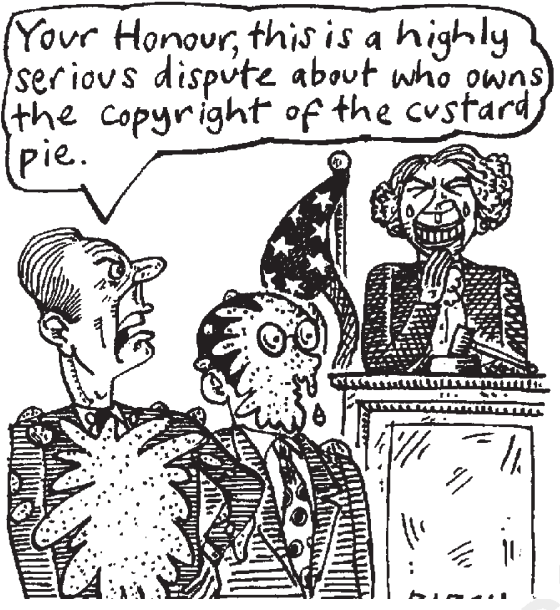

claim to the 'Igs'. Alexander Kohn — an

Israeli physicist who co-founded JIR in 1955 and then co-founded AIR (with Abrahams) in 1994, shortly before his death presented several 'Ignobel' prizes in a 1968 $J I R$ article that contained perhaps the first published reference to the concept. Kohn encouraged Abrahams to award such prizes at the new ceremony he started in 1991.

In The Scientist in 1996, Scherr argued that "neither Abrahams nor AIR were ever associated with the Ig Nobel Prize". But this has been challenged by Nobel laureates Richard Roberts and Dudley Herschbach, both of whom thought they had participated in numerous Ig ceremonies hosted by Abrahams. "Could it be that Scherr and I inhabit parallel universes?” Roberts asked.
Abrahams is equally baffled by the lawsuit, which seeks to prevent him from publishing any journal that (at least in Scherr's mind) is likely to be confused with JIR. Abrahams contends that the names AIR and JIR are not, as Scherr argues, "confusingly similar".

But to further dispel any possible misunderstanding, Abrahams has printed a disclaimer in AIR stating that the magazine "is in no way associated with that publication $[J I R]$ or with its publisher".

Abrahams says he cannot understand why he has been charged with "conspiracy" as no one else is mentioned in the lawsuit. "Evidently I've conspired with myself," he says. He is also astounded by the huge sum that Scherr hopes to collect, given that AIR has only 2,000 subscribers who pay just $\$ 23$ annually. "Why $\$ 4.2$ million? Why so low?" Abrahams jokes. "Doesn't Scherr respect me?"

On a more serious note, he has enlisted the help of Nobel laureates Herschbach, Roberts and William Lipscomb to launch the "Strategic AIR Defense Fund" to support his legal fight.

Abrahams speculates that his science humour colleague is making a serious bid for an Ig Nobel Prize. The situation is not one Abrahams imagined three years ago when he started his humour magazine. "I just want to be able to write and edit some funny things about science and maybe do some good along the way," he says. "I have no idea what Scherr wants." Steve Nadis

\section{Netanyahu bolsters opposition to dismemberment of ministry}

[Jerusalem] Israel's Prime Minister, Binyamin Netanyahu, has made it known that he opposes plans to dismantle the country's Ministry of Science, following an outcry from the scientific community.

The proposal to break up the ministry and transfer most of its grant-making authority to a national research and development council was made to the government last month by the minister of science, Michael Eitan. Eitan argued that such a reorganization would eliminate unnecessary administrative costs, and increase the amount of public funds available for basic and long-term research.

Eitan has subsequently admitted to the science committee of the Knesset - Israel's parliament - that he might have made a tactical error in proposing the dismemberment of the ministry. He has therefore offered to withdraw that part of his plan. But he continues to advocate the establishment of a single council to coordinate the government's science policy.

This body would coordinate all publicly funded support for research and development, including both the directed long-term research supported by the current ministry and the applied research funded by the Ministry of Industry and Commerce and other ministries.

Eitan suggested that administrative work associated with grants should be carried out by the industry ministry, and that a minister of science should continue to bear responsibility for government science policy, but working from the prime minister's office rather than heading his or her own ministry.

Eitan claimed that the finance ministry had promised that, if the reorganization programme was adopted, his ministry's entire budget — some US\$220 million would be made available for basic and longterm research grants. More than half of the science ministry's budget is at present spent on administration and other research and education programmes.

But his proposals generated a protest from most of Israel's scientists. A petition opposing the plan collected the signatures of more than 700 scientists at all seven Israeli research universities. Three former ministers of science voiced objections, as did the deputy minister of defence, Silvan Shalom, who is due to take over the science ministry next summer, under a rotation arrangement with Eitan (see Nature 388, 221; 1997).

"Decentralizing authority over science can harm science, especially in the long run," argues Professor Arie Admon of the Technion, the Israel Institute of Technology. Without an interested party such as a government ministry to fight for the science budget, he says, funding will inevitably decrease in the long run. Admon also claims that the science ministry has been highly successful in planning and coordinating research among Israel's universities.

Netanyahu's opposition to the dismemberment of the science ministry was announced by his science adviser, Israel Hanukoglu. Criticism has also come from the Knesset's science committee and from the former minister of science Ze'ev Binyamin Begin.

HaimWatzman 